\title{
OPPORTUNITIES AND CHALLENGES OF HOME-GROWN SCHOOL FEEDING PROGRAMME: A CASE OF WESTERN PROVINCE, ZAMBIA
}

\author{
Constance Sitali ${ }^{1} \bowtie$ \\ ${ }^{1}$ Kwame Nkrumah University - Kabwe, Zambia.
}

Received 1 September 2021

Accepted 15 September 2021

Published 30 September2021

\section{CorrespondingAuthor \\ Constance Sitali, \\ sitaliconnie@gmail.com \\ DOI \\ 10.29121/granthaalayah.v9.i9.2021. 4268}

Funding: This research received no specific grant from any funding agency in the public, commercial, or not-for-profit sectors.

Copyright: (C) 2021 The Author(s). This is an open access article distributed under the terms of the Creative Commons Attribution License, which permits unrestricted use, distribution, and reproduction in any medium, provided the original author and source are credited.

\section{ABSTRACT}

Home-grown school feeding (HGSF) is an innovative approach to school meals that encourages school to source nutritious food from local smallholder farmers. Therefore, the purpose of this study was to find out the opportunities and challenges of Home-grown school feeding in Western Province of Zambia. The study was guided by the theory of change by Weiss. Being a qualitative study, descriptive approach was used as a design. A total of 81 informants were targeted; 10 headteachers and 30 teachers from 10 public primary schools, 40 selected smallholder farmers from communities around schools and WFP Provincial Officer. Purposive sampling procedure was used to select the informants as they were directly involved in the school feeding while simple random sampling was used to select 10 public primary schools in 5 districts. The instruments used for data collection were semi-structured questionnaires and face to face interview guide. Qualitative data obtained were transcribed, analysed thematically and presented descriptively with verbatim quotes. The study revealed that HGSF has several opportunities, namely; equitable access to education, foster local economic, stimulating agriculture growth, food security and nutritious foods, diversification of local production, job creation, access to additional market and capacity building among others. Further, despite multiple opportunities, the study was characterized by some challenges such as climate change resulting in an unpredictable weather pattern, inconsistency in supply of food to schools, frequent rise of food prices affecting household food access, low level of agriculture technology and high dependency on rainfall for farming activities, the use of centralised approach to procurement of food, price volatility and unpredictable markets, lack of infrastructure and water scarcity. The study recommended that the Government should put in place a set of mechanisms that assist smallholder farmers in applying good agricultural practices and enhance their adaptability to climate change.

Keywords: Home-Grown School Feeding, Opportunities, Challenges, Smallholder Farmers

\section{INTRODUCTION}

Home-Grown School Feeding Programme (HGSFP) is an attempt activity and explicit, to link agricultural development with school feeding. It constitutes a school feeding model which relied mostly on external funding or rather foreign food aid, especially in low and lower- middle income countries. School feeding programme is generally considered primarily as education intervention that facilitates equal access to education and learning opportunities. School feeding is an established development aid intervention with multiple objectives including education, nutrition, health and value transfer. It has been implemented in different parts of the world with different purposes. The variation on purpose is 
determined by the need, resources and policies in the given country context Bundy et al. (2009). World Food Programme has successfully implemented school feeding programme for over 50 years. Its vision is to reduce hunger among school children so that hunger is not an obstacle to their development Bundy et al. (2009). This has led to further studies of how school feeding should be implemented in low-income countries to reach all hungry school children in need, in a way that is sustainable. Therefore, recent rethinking by the World Food Programme and World Bank has prompted a shift toward long-term, sustainable solutions that rely more upon local resources, local capacity, and community participation WFP (2013). The innovation for linking school feeding to local agricultural production as a way to increase the sustainability of the programme begins with the demand shift to national ownership through Home-grown school feeding.

The Homegrown School Feeding concept has been adopted by many countries in low and middle income as one of the key programmes in the provision of meals in schools WFP (2009). It is designed to provide children in schools with diverse and nutritious food, sourced locally from smallholder farmers.

The HGSF approach is increasingly recognised as a means to support smallholder farmers and the development to local communities Gelli et al. (2012). It has the potential to contribute to the achievement of the sustainable development goals (SDGs) related to food security, nutrition, education, health and agriculture FAO (2018).

In 2011, after 8 years of school feeding operations in Zambia, the government and WFP identified the HGSF model of school feeding as a sustainable way to link meal provision in schools to local community development by stimulating agricultural growth, thereby benefiting both school children and farmers. WFP-GRZ (2014). In Western Province, most of the children from pro-poor and food insecure households attend school irregularly or drop out of school completely due to hunger. The Zambian government in partnership with WFP through the HGSF, a food-based safety net, play an important intervention by narrowing the hunger gaps between the 'have' and the 'have not'.

However, the opportunities and challenges of home-grown school feeding vary from country to country. Therefore, this study intended to find out opportunities and challenges associated with Home-grown school feeding in Zambia, particularly Western Province.

\subsection{THEORETICAL FRAMEWORK}

This study was guided by the Theory of Change Wess (1995), which is a model that articulates, in a systematic way how strategies, activities or programme contributes to a set of specific outcomes through a series of intermediate results. Weiss popularized the term 'Theory of Change' as a way to describe the set of assumptions that explain why an intervention is needed, how it would work and what it would achieve. It is a theory of how and why an initiative works which can be empirically tested by measuring indicators for every expected step on the hypothesized causal pathway to impact. The theory is built upon beliefs and assumptions about what needs to take place and incorporates an understanding of how the context might support or hinder the success of an intervention. Theory of change explains the process of change by outlining causal linkages in an initiative, that is, its shorter-term, intermediate, and long-term outcomes. The theory was used alongside the model of transition from School Feeding Programme to Home Grown School Feeding. It is theorized that HGSF programme can deliver a wide variety of outcomes. The theory was viewed as a guide to understanding HGSF and provided 
a framework about how the intervention makes contribution. Framing the study using the theory of change helped the study to identify and explore the pathway through which homegrown school feeding may provide an interface to promote agricultural production diversity.

\section{LITERATURE REVIEW}

Various studies have been done in relation to school feeding programme. The programme is viewed as a potential safety net and social support measure that help keep children in school and protect nutritionally vulnerable groups Harper et al. (2008). The World Food Programme estimates that about 73 million children globally do not have access to the nutrition they need to complete their education successful. It was estimated that 65.4 million children receive school meals across Africa World Bank (2018). In the United States preventing hunger pain and nervousness related to hunger was a key objective of school feeding programme in times of scarcity. In United Kingdom, school feeding was considered as a matter of national safety (Levine, 2008). With other health problems rising globally in recent years, the aim of school feeding has changed in the United Kingdom and United States and may also change in other countries depending on the situation of priorities.

According to Evans and Harper (2009) and Harper et al. (2008), all school children in high and upper-middle-income countries have access to school meals, the most vulnerable children are entitled to free or subsidized meals and the programme is well institutionalized in national policy framework and systems. The programme is less universal in low and low-middle income countries; frequently supported by donors and programme implemented by development partners.

In Africa, work on school feeding is driven by the New Partnership for Africa Development (NEPAD) which is an African Union strategic framework for socioeconomic development. The link between school feeding and local agricultural production that is home-grown school feeding is one of the key initiatives of CAADP, which was established in 2003 by NEPAD.NEPAD aims to increase children direct access to food through school feeding programme, with a target of 50 million children of school going age by end of 2020 WFP (2009). Several partners, including WFP, the World Bank and PCD, provide support to governments under the CAADP framework which provides Africa and its partners with a set of goals and results to be pursued in the transformation of the agriculture sector. In many countries, this has been a challenge to ensure effective mechanisms through which donors and partners can effectively coordinate their inputs and support.

In 2003, African governments decided to include school feeding that source food locally from smallholders in the comprehensive Africa Agriculture Development Programme CAADP. The New Partnership for Africa's Development (NEPAD) launches home-grown school feeding pilots in Cote d'lvoire, Ghana, Kenya, Mali, Nigeria, Tanzania, Ethiopia, Malawi. Mozambique, Senegal, Uganda and Zambia. HGSF is recognised by NEPAD and CAADP as an initiative that promotes food security and rural development. Home-Grown School Feeding Programme which is designed to supply food for school feeding from purchases and procurement of locally produced food, enhances the domestic production and demand for food Ahmed (2004).

According to WFP and PCD (2010), the government of Cote d'Ivoire began its 'one school, one canteen' programme in partnership with the Ministry of Agriculture. The programme which provides school meals to children including, a component of technical and financial support to smallholder farmers, to link school 
canteens with smallholder farmer production. Another country is Mali, the programme was initiated by the WFP and the Catholic Relief Services as a strategy to reduce poverty. In 2009, a national policy on school feeding was adopted Diallo (2012). After the adoption of the national school feeding policy, the national school feeding programme was launched in 2011 Kremer and Vermeerch (2017). The programme promotes locally-owned school feeding programme, benefiting communities through community organisations, providing training, and supporting smallholder. Further, school feeding activities in Kenya was introduced in 1979 with its popular school milk programme but later, it was shut down due to high costs and the introduction of the Structural Adjustment Programme. According to Langinger (2011), a school feeding partnership between the government of Kenya and WFP started in 1980 in response to increased frequently of food insecurity which came as a result of drought and political instability and to the introduction of free compulsory primary education in 2003. The programme in Kenya increased significant and in 2008, the government of Kenya took over the obligation of school feeding programme. In 2009, the Kenyan government introduced home-grown school feeding that had intention of curbing malnutrition among children, increasing access to education and reducing social pressure that keeps girls away from school Langinger (2011).

Home-grown school feeding has double effect in that it targets both small scale farmers and school aged children WFP (2009). Through the HGSF, farmers' returns are enhanced not just through their access to school feeding but also through providing the necessary market while defending them from the elevating costs of food Kumar (2011). The HGSFP, therefore, eliminates universal hunger and poverty through generating sustainable earnings for the small-scale farmers Kumar (2011).

For the HGSFP to be successful there has to be a strong commitment and involvement from community members WFP (2013). The WFP further reports that the HGSFP easily avails meals that are varied, good quality and healthful as the food products are fresh, which assist children in being fit and always available for learning. Upton and Jentz (2011), postulate that purchasing locally saves costs and benefits faster delivery of food.

In Zambia, school feeding programme commenced in 2003 while Home-grown school feeding was introduced in 2011. Since then, World Food Programme, endowed with long years of experience in school feeding activities, has multiplied its effort to aligning the HGSF programme with national policy framework and creation of a sustainable national owned school feeding programme WFP-GRZ (2014). WFP has been called to do more to address problems related to chronic hunger, and poverty which are real obstacles to long-term national development and has also supported interventions that nurture self-reliance while ensuring short-term food needs are met GRZ (2014). Under the Zambian country Strategic Plan (CSP) 2019-2024, WFP provides food assistance to vulnerable and foodinsecure people, including on-demand logistics support during emergencies. WFP also supports integrated nutrition and smallholder farmer support in food-insecure areas, and helps strengthen the capacity of the government to implement national programme and systems that contribute to zero hunger and improved nutrition. HGSF approach has been identified as one of the critical elements in transitioning to sustainable programme. Sumberg and Sabates-Wheeler (2011).

\section{RESEARCH METHODOLOGY}

The study sought to find out the opportunities and challenges of home-grown school feeding programme in Western Province of Zambia. Being a qualitative study, descriptive approach was used as a design. The study was guided by the theory of 
change by Weiss. Qualitative research was chosen for its potential of yielding a deeper understanding of a social phenomenon from the perspective of the participants and it relies on a research strategy that is flexible and interactive. A total of 81 informants were targeted; 10 headteachers and 30 teachers from 10 public primary schools, 40 smallholder farmers from communities around schools and WFP Provincial Officer. All the informants were Purposively sampled as they were directly involved in the school feeding programme while simple random sampling was used to select primary schools in 5 districts. These districts have been purposively selected due to the fact that they are inhabited by many smallholder farmers characterized by different attributes The instruments used for data collection were semi-structured questionnaires and face to face interview guide. Qualitative data obtained were transcribed, analysed thematically and presented descriptively with verbatim quotes.

\section{FINDINGS AND DISCUSSIONS}

\subsection{OPPORTUNITIES OF HOME-GROWN SCHOOL FEEDING}

All the informants (Headteachers, teachers, WFP provincial officer and smallholder farmers) were asked to find out the opportunities associated with home-grown school feeding programme. The responses were as follows:

Headteachers and teachers indicated that HGSF had education opportunities. One headteacher shared his experience as follows:

Home-grown school feeding can improve access to education outcomes. As education intervention that facilitate equal access to education and learning opportunities; it can help maximise the return on investment in education and contribute to reducing poverty in the long term.

Similarly, one teacher reaffirmed the disclosure made by the previous informant. She had this to say:

"HGSFP is seen as an opportunity to find an alternative and appropriate approach that will make feeding school children possible so as to enhance academic performance and promote consistent learning in primary schools. It should also improve a child's growth and development."

Home-grown school feeding provides farmers with steady demand which allow them to make investments and to send their children to school. This increases their productivity which creates jobs and profits which allow communities to strengthened economies.

In addition, another teacher referred to nutrition as one of the opportunities associated with HGSF. This is what the informant said:

"Food availability and better access to adequate food will be assured and our learners eat indigenous quality and fresh foods direct from the farm to the mouth of the child." The informant further said, "The food we purchase and produce locally, improves nutritional status of our children"

Such response as above can explain that HGSF has a potential to increase demand for health and nutritious foods. This implies that nutritious and diversified meals received at school can contribute towards shaping children's tastes and preferences and shape future demand for health and nutritious foods Nutrition behaviour learnt in school can have a lifetime impact for children, their families and communities. This view was supported by the WFP (2013) report which stated that home-grown school feeding programme easily avails meals that are varied, good quality and healthful as the food products are fresh. 
WFP provincial officer revealed the economic opportunity, and this is what the officer said:

"HGSF promotes food security by improving the productivity and income of smallholder farmers; make food systems sustainable and create predictable and structured market for local produce."

This is in agreement with the findings by Kumar (2011) who revealed that home-grown school feeding farmers' returns are enhanced not just through their access to school feeding but also through providing the necessary market. This approach enables more direct contact with food-supplying farmers from the community where the programme is implemented, and can bring market opportunities and development for them.

One smallholder farmer also revealed that home-grown school feeding has a potential to promote economic opportunity.

"Local economies would be promoted, as those not employed would get job opportunities through the production and purchasing of community grown products, which brings profits for the small-scale farmers."

This entails that changing lives for smallholder farmers aims to highlight the achievement to support smallholder farmers with opportunities that enable them to transition from being recipients of food assistance to self-reliance.

The home-grown school feeding approach is seen not only to improve access to education and health outcomes but also farmers' livelihoods through increased productivity and production. An increase in local food production provides adequate food for school feeding. Furthermore, increased local food production leads to increased food security, which, in turn improves household income. This approach guarantees that the food supplied is produced within the community and that the income generated contributes to the local economy. The resulting increase in production will provide a higher income to the farmers which can bring positive protective, preventive and promotive social protection impacts.

Another smallholder farmer had this to say: "HGSF offers the farmers the opportunity to produce more food to sell to schools, and to reduce food loss."

The programme also improves the economic conditions to local communities' members, of whom many are involved in the preparation of the meals served. This is in line with WFP (2013) when revealed that home-grown school feeding to be successful, there has to be a strong commitment and involvement from community members.

One of the teachers said the following:

"To transition from externally supported of project to nationally owned programme is yet another opportunity of home-grown school feeding, since our school feeding has been associated with imported food aid".

This showed that the school feeding programme could be better sustained if schools purchased their food from local farmers or produced their own foods from school production units. This is in line with Sumberg and Sabates-Wheeler (2011) who approved that the innovative element of HGSF is in supporting smallholder farmers to enable them to gain access to a predictable and stable local market and to maximize the benefits that they can derive from such access.

Social protection is another opportunity highlighted by the WFP officer. He had this to say:

"As part of a social protection system, it promotes human capital in the long run by supporting families in securing education for their children, and provides direct support to poor households in the short term by transferring income to the families." 
Oftentimes, home-grown school feeding programme is classified as social safety nets, that is, as a means to provide assistance to poor and food insecure people and predominantly school children. The programme acts as a catalyst for household food security and income. HGSF has become integral element of national long-term strategies to help people move out of poverty. This is well reflected in the commitments of the African Union and the New Partnership for Africa's Development (NEPAD).

WFP Provincial officer and some smallholder farmers identified extension services as an opportunity. This is a shift of skills and knowledge from technocrats to community members.

WFP officer had this to say:

"Farmers receive information and knowledge on adaptation of strategies like crop diversification which should include shift to growing drought resistance and early maturity crop varieties such as cassava, sorghum, soya beans, sweet potatoes and millet."

This was in accordance with Sumberg and Sabates-Wheeler (2011) who stated that linking school feeding to local agricultural production is seen as a way to ensure sustainability and take advantage of a range of potential opportunities. However, despite farmers adapting strategies such as crop diversification, there is a dire need for the government to empower rural household with farming inputs such as animal draft power, ploughs, simple irrigation equipment, seed and fertilizers. This would ensure farmers planting early, and having good harvest.

Still on extension services; responses from farmers include:

"WFP distributed rippers to us farmers as part of efforts to address the challenges of land preparations." Further, the same informant added to say: "WFP also facilitated the training of master trainers in climate services."

"WFP facilitated the installation of manual rain gauge and some of us were privileged to be among those who were trained in collecting, interpreting and disseminating rainfall information to other smallholder farmers to enhance decisionmaking in agricultural production and enable them to prepare for eventual climate shocks."

"Our groups were visited by the nutritionists and the focus was on types and quality of foods, storage, preparation and how to preserve local foods. As a farmer the lessons were very beneficial."

This programme supports rural women's production and incomes. It fosters women's participation in farmers' organisations, and reinforce rural women's selfconfidence, knowledge and skills through training and learning.

Headteachers and teachers revealed that WFP, continued to strengthen the capacity of the Ministry of General Education by facilitating the training of teachers and district staff in the implementation of the home-grown school feeding programme. Further, they also revealed that the staff from schools were trained on Food Tracking System (FTS), a web-based platform developed for Ministry of General Education to track the movement of commodities from procurement to consumption, which in turn improves commodity accountability in the HGSF programme.

\subsection{CHALLENGES OF HOME-GROWN SCHOOL FEEDING}

To find out the challenges of home-grown school feeding programme, the informants were asked to give out their views. The findings were as follows: 
One of the smallholder farmers had this to say: "As farmers, we try our best in terms of farming, even planting early, but most of the times we are disappointed with poor yield due to weather extremes."

This finding implied that, climate change resulting in unpredictable weather pattern can affect the yield production either positive or negative. Most of the production of the smallholder farmers depend on the rain fed production because they lack irrigation facilities. Any effect whether floods or droughts has negative impact on yields in turn it affects the smooth running of the school feeding programme and community food security. For instance, 1989/1990 and 2018/2019 farming seasons when the part of the country experienced drought and other parts received above normal rains which led to floods result in crop failure.

In an interview with the WFP Provincial officer, the issue of inconsistency in the supply of food to schools was raised as a challenge. This is what the informant disclosed:

"The question of farmers' ability to consistently produce the right quality and quantity of food, and their ability to get the food to the schools when it is needed is a challenge."

Food production may not be possible in some locations and small-scale farmers may have little or no experiences with selling to the school food market because they tend to produce primary for their household's needs. According to the researcher, this implies that the challenge is linked to the home-grown school feeding goal of purchasing at least a portion of the school food from small-scale farmers. School food must be available in adequate quantity throughout the school year

Headteachers and teachers revealed that home-grown school feeding model had experienced some challenges. Among other challenges; lack of infrastructure and water scarcity. These include cooking shelters, water supply to schools and cooking utensils. In rural communities, this means that smallholder farmers do not necessarily have the capacity to meet the demands of schools. This leads school committees to procure food from traders, who may not be local. In this way, rural smallholder farmers are not always receiving sufficient benefits from HGSF intended to alleviate poverty and meet the zero-hunger challenge.

Other teachers and smallholder farmers mentioned some of the challenges of home-grown school feeding such as inability to produce enough food, frequent rise of food prices affecting household food access, low level of agricultural technology and high dependency on rainfall for farming activities.

Furthermore, World Food Programme officer disclosed that some challenges like the use of centralised approach to procurement of food include price volatility and unpredictable markets, both of which home-grown-school feeding programme help to alleviate.

\section{CONCLUSION}

This initiative was a transformation from an unsustainable externally supported project to nationally owned programme for sustainability. Home-grown school feeding is designed to stimulate local production through the purchase of locally produced food for schools or produced their own foods from school production units. Meaning local smallholder farmers will be given opportunity, alongside with initial assistance to provide schools with necessary food products.

Home grown school feeding programme has emerged as an opportunity to improve the livelihoods of smallholder farmers and local communities, and strengthen the link between nutrition, agriculture and social protection through 
food production and economic opportunities for local communities. The programme has the potential to transform local communities, both economically and socially by involving several groups within the community in the programme. These groups include; children who receive school meals and their families, local smallholder farmers who are contracted to provide food for home-grown school feeding and local workers who are employed at participating schools. In addition, this programme can contribute strongly to the achievement of Sustainable Development Goals (SDGs) in food security, nutrition and health, education and agriculture.

However, it was also evident from the findings that Home-grown school feeding programme was characterized by several challenges including: climate change resulting in an unpredictable weather pattern, inconsistency in supply of food to schools, frequent rise of food prices affecting household food access, low level of agriculture technology and high dependency on rainfall for farming activities, the use of centralised approach to procurement of food, price volatility and unpredictable markets, lack of infrastructure and water scarcity.

In line with the Theory of Change and the integration approach, the country has taken a paradigm shift toward the school feeding. If well designed with the homegrown school food supply component, the programme has the potential to benefit the entire community through stimulating local markets, facilitating agriculture transformation and enabling households to invest in production assets. The programme is expected to generate a number of impact pathways, some of which relate to agricultural growth while others relate to food security and social protection. The approach can achieve sets of outcomes; short-term and long-term poverty reduction, income support and stabilisation as well as social transformation.

\section{RECOMMENDATIONS}

- The Government of Zambia should put in place a set of mechanisms that assist smallholder farmers in applying good agricultural practices and enhance their adaptability to climate change.

- The Government should also invest in rural infrastructure and improving agricultural capabilities through irrigation systems and farming technologies.

- The government should come up with a policy that incorporates school feeding, nutrition and health.

- The Government should direct the School Managements to revamp the production unit in all the schools.

\section{REFERENCES}

Ahmed, A, U. (2004). Impact of Feeding Children in school: Evidence from Bangladesh, International Food Policy Research Institute (IFPR) Washington: DC. Retrieved from https://d1wqtxts1xzle7.cloudfront.net/41381741/wfp121947-withcover-pagev2.pdf?Expires $=1633501362 \&$ Signature $=$ AXZOMvOmXkgcMvsL81f $\sim$ N65m 8e3u5JvHol3DA9jHt tNq07jVVpQPbZQ9iCQIPJ70zXFrrySOYcDxnnT8johQ J0NP5HXhFPnDzBPsNlKu9IVjAr6MSLDHva826PkhWssFH1w764KDRdE8T eYr0toTbmS823GFDsCcP-BcYnbCQTF7rbugJuA9iI9SeVCv6kFP5yze91zrcmTOtw9Qka0Q6tptaNU5niJLZ8eSQ1yXKVq 3U7Mcky075gw-x5L60- 
FVGgquYh8pyGUMzGwiMh05zKmP54pgfXGeIsosJU9t4lGzLfUw57g49w6MX505CT OnpB2S000MtXiRPrXTEQ_\&Key-Pair-

Id=APKAJLOHF5GGSLRBV4ZA

Alderman, H. \& Bundy, D. (2012). School feeding programs and development: Are we framing the question correctly? Retrieved from https://doi.org/10.1093/wbro/lkr005

Bundy D., Burbano C., Grosh M., Gelli A., Jukes M. \& Drake, L. (2009). Rethinking school feeding: Social safety nets. Washington: DC, World Bank. Retrieved from https://doi.org/10.1596/978-0-8213-7974-5

Diallo, A. S. (2012). Evolution of School Seeding in Mali. The Partnership for Child Development (PCD) disadvantaged students. The Cochrane Collaboration: John Wiley \& Sons, Ltd.

Evans, C.E.L \& Harper, C.E. (2009). A history and review of school meal standards in the UK, Journal of Human Nutrition and Dietetics. 22(2): 89-99. Retrieved from https://doi.org/10.1111/j.1365-277X.2008.00941.x

FAO \&WFP (2018). Homegrown SFP, Resource Framework Technical Document. Rome.

Gelli, A. et al. (2012). A comparison of supply chains for school for All: Levelling the Playing Field. Cambridge, MA: CABI Publishing.

Gunderson, W.G. (2003). The National School Lunch Programme: Background and Development. Nova Publisher PP1-6 ISBN 978-1 59033-639-7.

Harper, C Wood and Mitchell, C. (2008) The provision of food in 18 countries. London: The School of FoodTrust.

Kremer, M \& Vermeerch, C. (2017). School Meals, Educational Achievement and School Competition: Evidence from a randomized evaluation World Bank Policy Res. Work. Pap.3523.

Kumar, S. (2011). State of the World. Innovation that nourishes the Planet. Retrieved from http://ww.blogs.worldwatch.org/nourishing the Planet

Langinger, N. (2011). School Feeding Programs in Kenya: Transition to a HomeGrown Approach. Stanford Journal of International Relations. Vol 8 (3), 3037. Retrieved from https://www.dlci-hoa.org/assets/upload/combineddocuments/20200804031615899.pdf

Sumberg, J. \&Sabates-Wheeler, R. (2011). Linking Agricultural Development to School Feeding in Sub-Saharan Africa: Theoretical Perspective Food Policy. Retrieved from https://doi.org/10.1016/j.foodpol.2011.03.001

Upton, J.B \& Jentz, E.C. (2011). Expending the Food assistance. Initiating on Food Assistance: A case for Transaltantic Policy Convergence 75-100. London; Routledge.

Wess, C. (1995). Nothing as practical as Good Theory: Exploring Theory-Based Evaluation for Comprehensive Community Initiatives for children and families (Connell, J; Kubisch, A; Schorr, L \& Weiss, C. (Eds) 'New Approaches to Evaluating Community Initiatives 'ed). Washington, DC: Aspen Institute.

World Bank (2018). The State of Social Safety Nets. Washington, DC. World Bank.

WFP (2009). Rethinking School Feeding:Social Safety nets, Child Development, and the education Sector nets. Washington: DC.World.

WFP (2013). State of the School Feeding Programme. Rome: WFP.

WFP-GRZ (2014). Home Grown School Feeding Programme Annual Report: Western Province, Zambia 